Serene Dalati,

Ph.D., Arab International University, Syria

ORCID ID, 0000-0002-4523-4068

email: s-dalati@aiu.edu.sy

Jurgita Raudeliuniene,

Ph.D., Vilnius Gediminas Technical University, Lithuania

ORCID ID, 0000-0003-4003-0856

email: jurgita.raudeliuniene@vgtu.It

Vida Davidaviciene,

Ph.D., Vilnius Gediminas Technical University, Lithuania

ORCID ID, 0000-0002-0931-0967

email: vida.davidaviciene@vgtu.lt

Correspondence author: jurgita.raudeliuniene@vgtu.It

\title{
INNOVATIONS IN THE MANAGEMENT OF HIGHER EDUCATION: SITUATION ANALYSIS OF SYRIAN FEMALE STUDENTS EMPOWERMENT
}

Abstract. Syrian women face many barriers and restrictions on the way to legitimate their roles in the formal economy and the higher education sector. This paper examines the higher education environment in Syria, highlighting the situation after 2011. The purpose of this research is to conduct a situation analysis of Syrian female students' empowerment in the higher education environment. The study object is the private Syrian university used to identify the main barriers and restrictions in the higher education sector and determine training areas for solving before-mentioned issues. The methodology applied in this research employs a quantitative approach through the design of a structured questionnaire. The findings exposed the importance to develop further investigations on the integration of gender equality into the university strategy. Therefore, a lack of awareness of gender equality and equity is a significant area for development and study at Syrian universities. The obtained results in the field of female students' empowerment demonstrated the adequate levels of motivation to pursue a career in academia and interest in studying gender-oriented courses. However, gender issues have not integrated into the university course offerings and curriculum. This study covers the policies related to institutional support are areas of investigation. Besides, the research results showed that stereotypes and social expectations exist are considered to be the challenges that require examination. Technological skills, soft skills, and leadership skills were determined as an array of training that was needed by female students. Self-empowerment was recognized as critical training for female students. Developing management, leadership, and networking skills were also identified as a training need for female students.

Keywords: female, gender, student, higher education, women empowerment, university.

Introduction. Based on numerous research results, women in Syria face many barriers and various restrictions that often preclude access to legitimate roles (managerial positions, board membership, etc.) not only in the formal economy but also in the higher education sector (Sidani 2005; 2016; Sindi 2015; Afiouni et al., 2020; Makarem et al., 2019). For solving before-mentioned issues, this research examines a situation analysis of Syrian female students' empowerment at Arab International University by investigating dimensions, which influence female students' experience and career progression. The study explored the diagnoses of female students' status quo representation of the training field's needs. The research inspects a private institution examining circumstances after 2011 (Al Azmeh et al., 2020; Alamir et al., 2019; Dalati et al., 2018). The methodology of this research is a survey (questionnaire) applied to identify Syrian female students' current situation in a higher education environment. In this study, a quota

Cite as: Dalati, S., Raudeliuniene, J., \& Davidaviciene, V. (2020). Innovations in the management of higher education: situation analysis of Syrian female students empowerment Marketing and Management of Innovations, 4, 245-254. http://doi.org/10.21272/mmi.2020.4-20 
sampling technique is applied. The size of the sample is 98 cases distributed across seven faculties. The research analyzes the situation of Syrian female students' empowerment in the higher education environment at individual and organizational levels. Research results demonstrate a critical need for training areas of technological, soft and leadership skills and awareness in topics of gender educationrelated courses such as social justice and gender equality.

Literature Review. The new reality in higher education requires modern sustainable leadership approaches (Dravet and Castro, 2019; Muborakshoeva, 2019). The twenty-first century brings new priories and management style which could transcend time, place, geography, race, and above all gender (Dalati 2017; Dalati et al., 2017; Segovia-Perez et al., 2019; Howard-Grenville et al., 2017). Education is one of the priorities, which becomes a crucial dimension in shaping human lives for an effective and sustainable future (Bordoloi, 2018). Empowering women in academia become a vital initiative to actively encourage women to participate in the academic community and achieve individual career goals. Besides, there is a significant demand to enhance women's representation and management status (Malik and Courtney, 2011; Moodly and Tony, 2019). Previous studies on the Middle East and South Mediterranean region indicate that building capacity for women academics is critical.

Enhancing female academics capacity in terms of professional, personal, social, or management competencies through knowledge, abilities, and skills is essential. Interpersonal, digital and problemsolving skills are necessary for this new era of female academic leadership. However, there will always remain obstacles, which could impair this disadvantaged group from accelerating to take leadership management positions. These barriers could be classified as social, cultural, economic, and related to stereotypical attitudes on gender roles. Women in management positions in academia could significantly impact their countries and the region in different spheres such as economics, politics, society, and, most importantly, as academic leaders initiating change in the educational field. Gender inequality reflects negatively on society's human, social, economic, and political aspects (Braunstein and Seguino, 2018; Danylova and Kats, 2019; Popp et al., 2019). In turn, establishing economic independence across both men and women has a positive impact on the economy and will better utilize human capital in a given nation. Therefore, equality is considered as the cornerstone and fundamental principle on which the European Union has based its foundation (European Union, 2012). It worth mentioning that the European Union has developed some directions to initiate and build gender equality. Based on previous research results, gender disparity is displayed in different sectors where women are overrepresented in lower-paid sectors and underrepresented in senior management levels and decision-making positions (Raudeliuniene et al., 2020; Raudeliuniene et. al., 2018a; Raudeliuniene et al., 2018b). There is a growing tendency of research, which indicates that women go through gender-based inequalities during their education and career path (Gracia, 2009). Herewith, the global gender gap index is measured in four dimensions as follows: economic participation and opportunities, educational attainment, health, survival, and political empowerment (Al-Salem and Speece, 2017). It stands to mention that the economic participation sub-index as a significant indicator could be considered in the following aspects: the participation gap, the remuneration gap, and the advancement gap (Hausmann et al., 2010). Besides, education attainment is a sub-index indicator with a crucial significance for this research. In turn, educational achievement is signified by examining the gap between men's and women's access to education through ratios of female to male in primary, secondary, and tertiary levels of education as well as female versus male literacy rates (World Economic Forum, 2018; Thakur et al., 2018). Based on previous studies on the Middle East and Arabic regions, there are encouragement and enhancement of women's education. However, enhancing female education is not effective in enabling women to take full advantage in terms of employment and occupation. In Arabic societies, education is not a valuable indicator of women's economic situation. Patriarchal values and practices are still dominant in Arabic societies due to the nature of the Arabic world's social culture (Dariel et al., 2017; Sultana et al., 2018; 
S., Dalati, J., Raudeliuniene, V., Davidaviciene. Innovations in the management of higher education: situation analysis of Syrian female students empowerment

Xheneti et al., 2019). It is strongly arguable that the higher education environment in Syria is considered with the following characteristics. Firstly, it lacks sustainable development in its initiatives and strategies. Second, it is deficient in establishing career counselling centres for female academics and students subject to different discrimination forms at higher education institutions. Third, it lacks the integration of gender issues and sustainability at curricula levels. Fourth, there is still a gap in scientific research development in the scope of gender equality, sustainability issues, and female empowerment.

The effect of this problem has resulted in a generation of female academics characterized by incompetence and insufficient knowledge, abilities and skills as executive managers at entry, mid and senior levels, as well as low power dead-end jobs. Notably, before the destructive war in Syria, private higher education institutions in Syria were continually increasing and competing to enrol students. At the beginning of 2011, the political crisis has torn Syria and created an overwhelming condition on political, economic, environmental, and social levels, including public and private higher education institutions (Al Azmeh et al., 2020; Alamir et al., 2019; Dalati et al., 2018). Nowadays, and after approximately ten years of war, destruction in political, economic, environmental, social and human levels leads to a search for new directions such as sustainable development and gender equality. These new perspectives are even more critical in Syria because of the economic situation, mainly reflecting on the social environment.

According to the United Nations Educational, Scientific and Cultural Organization, girls are the victims because of the large gaps in learning achievements and continuing their education compared to the other gender. Despite the improvement nowadays, more numerous of girls than boys stay out of school: 16 million girls will never set foot in the classroom based on their studies. Women account for two-thirds of the 750 million adults without basic literacy skills (UNESCO, 2019). Therefore, the main problem starts from childhood and primary school, as girls do not always have the same opportunities as boys to accomplish and benefit from an education they choose. A significant number of girls and women are restrained because of biases, social norms, and expectations affecting the quality of education they could receive and the subject they study (UNESCO, 2019). There are various factors which blocked girls and women from fully exercising their right to participate in self-realization and development processes like to complete and benefit from education. Notably, the factors mentioned above are such as poor conditions, geographical separation, different other circumstances as early marriage and pregnancy, gender-based violence, and traditional attitudes about women's status and role (UNESCO, 2019).

The analysis of scientific background indicates the growing research tendency on women leadership in higher education (Fonts, 2018). Thus, the study on Pakistan female students explored the effects of proactive personality, entrepreneurial self-efficacy, and perceived university support on female students' entrepreneurial intentions. This paper reported significant predictors of female students' entrepreneurial intentions (Hussain and Malik, 2018). According to a study conducted in India, there are a set of barriers associated with girls' education linked to the economic situation, cultural male-oriented environment, gendered biased stereotypes, and traditions (Bordoloi, 2018). However, a study conducted in Malaysia on graduate students' employability awareness underlines that female students are more informed than male students on skills requested by the industry. This research aims to examine the academic environment's diagnosis at a private university in Syria based on the factors affecting female students' personal and professional competence and career progression. In turn, the previous studies concerning the personal, social and professional competencies and women leadership (Raudeliuniene et al., 2020; Raudeliuniene et al., 2018a; Raudeliuniene, 2018b) allowed describing the competence as the integration of knowledge, abilities, and skills.

This study performs an analysis of Syrian female students' empowerment at individual and institutional levels. This work examines female students' motivation to work in the higher education sector, role model, and preferences for gender-oriented courses. At the institutional level, the study examines issues related to stereotypes, discrimination level, support, and potential training areas (personal and professional 
competence needs and essential areas of training). This paper presents recommendations related to identifying training areas to empower female students based on research results.

Methodology and research methods. This paper is based on a situation analysis performed in MayAugust 2019. The study explores Syrian female students at a private university in Syria. According to Ferrell and Hartline (2008), a thorough situation analysis empowers managers because it facilitates the analysis and synthesis of information (Ferrell and Hartline, 2008). The sampling strategy employed a nonprobability sampling approach. This type of sampling was selected to increase sample representativeness (Cooper and Schindler, 2013; Gomez and Mouselli, 2018).

The survey concentrated on considering personal, institutional dimensions, and competence development to be expressed via possible training needs. Herewith, the questionnaire comprised of closeended questions based on ordinal, nominal, and interval scales. The size of the sample consisted of 98 female students studying at seven faculties. The results of the analysis examine demographic profiles, different levels, and training needs. The sample study is distributed across seven faculties operating at Arab International University. In turn, 39\% of participants belong to faculty of Business Administration, $32 \%$ - the faculty of Pharmacy, 17\% - Fine Arts, 6\% - Architecture, 3\% - Information Technology, 2\% the faculty of Law, $1 \%$ - Civil Engineering. 36\% of study participants are in the age category of less than 20 , and $64 \%$ are between 20 and 25 years. Female students were distributed across years of study where $6 \%$ is the fifth year, $19 \%$ is the fourth year, $22 \%$ is the third year, $18 \%$ is the second year, and $35 \%$ is the first year (Table 1).

Table 1. Demographic profile for female students

\begin{tabular}{|c|c|c|}
\hline FACULTY & FREQUENCY & RESULT, \% \\
\hline Business administration & 38 & 39 \\
\hline Pharmacy & 31 & 32 \\
\hline Fine arts & 17 & 17 \\
\hline Architecture & 6 & 6 \\
\hline Information technology & 3 & 3 \\
\hline Law & 2 & 2 \\
\hline Civil engineering & 1 & 1 \\
\hline Total & 98 & $100 \%$ \\
\hline Age categories & Frequency & RESULT, \% \\
\hline Less than 20 & 35 & 36 \\
\hline 20 years -25 years & 63 & 64 \\
\hline Total & 98 & $100 \%$ \\
\hline Year of study & Frequency & RESULT, \% \\
\hline First-year & 34 & 35 \\
\hline Second-year & 18 & 18 \\
\hline Third-year & 21 & 22 \\
\hline Fourth-year & 19 & 19 \\
\hline Fifth-year & 6 & 6 \\
\hline Total & 98 & $100 \%$ \\
\hline
\end{tabular}

Source: developed by the authors.

Results. The results of the analysis were illustrated at individual and institutional levels. Factors examined at the personal level included female student motivation to choose an academic career, characteristics associated with a female role model, and preferred gender-oriented courses. While the factors studied at institutional levels were gender-oriented stereotypes and social expectations. At the individual level, the analysis of female students' motivation indicated that $67 \%$ of females had the motivation to follow an academic world occupation after graduation, while $33 \%$ did not.In turn, the results 
S., Dalati, J., Raudeliuniene, V., Davidaviciene. Innovations in the management of higher education: situation analysis of Syrian female students empowerment

of analyzing the reasons preventing them from choosing this career direction, $64 \%$ indicated that they realized better possibilities and options in other business sectors. Besides, $22 \%$ of respondents did not consider academia as a suitable occupation, while $11 \%$ were not interested in this career, and another $3 \%$ evaluated themselves as not good enough (Table 2 ).

Table 2. Female students' motivation to choose an academic career

\begin{tabular}{lc}
\hline \multicolumn{1}{c}{ Motivation level } & Result (\%) \\
\hline Female students believe that are better opportunities outside of academia & 64 \\
Female students believe that academia is not the right place & 22 \\
Female students are not interested in a career in academia & 11 \\
Female students don't have enough competence to stay in academia & 3 \\
\hline
\end{tabular}

Source: developed by the authors.

The next part of the analysis examined female students' perceptions of female role models. The descriptive research indicated that $83 \%$ of respondents experienced the presence of a woman academic professional who they perceived as a role model compared to $17 \%$ who responded otherwise. The results of female students' motives demonstrated that they perceived this role model as inspiring. Thus, $20 \%$ of students identified confidence, and 19\% indicated that the cause was related to expertise in the academic field. Besides, $17 \%$ of students underlined charisma, $13 \%$ considered the ability to uplift others, $12 \%$ - the ability to inspire, and $4 \%$ of respondents related to assertiveness (Table 3 ).

Table 3. Characteristics associated with the female role model

\begin{tabular}{lc}
\hline Characteristics & Result (\%) \\
\hline Confidence & 20 \\
Expertise in the academic field & 19 \\
Charisma & 17 \\
Ability to uplift others & 13 \\
Ability to inspire & 12 \\
Independence & 8 \\
Resilience & 7 \\
Assertiveness & 4 \\
\hline
\end{tabular}

Source: developed by the authors.

A question based on a ranking scale investigated female students' perception of female role models' characteristics in academia. Table 4 presents the obtained results as follows: $28 \%$ of students identified academic field expertise as the first crucial factor. In comparison, $22 \%$ indicated confidence as the second important characteristic, and $18 \%$ of respondents identified charisma as their third choice.

Table 4. Characteristics for female role model ranked by importance

\begin{tabular}{lcc}
\hline Characteristics & First & Second \\
\hline Expertise in the academic field & $28 \%$ & $16 \%$ \\
Confidence & $22 \%$ & $30 \%$ \\
Charisma & $18 \%$ & $16 \%$ \\
Ability to inspire & $14 \%$ & $15 \%$ \\
Independence & $8 \%$ & $8 \%$ \\
Ability to uplift others & $6 \%$ & $9 \%$ \\
Assertiveness & $2 \%$ & $4 \%$ \\
Resilience & $2 \%$ & $2 \%$ \\
\hline
\end{tabular}

Source: developed by the authors. 
S., Dalati, J., Raudeliuniene, V., Davidaviciene. Innovations in the management of higher education: situation analysis of Syrian female students empowerment

The results for gender education illustrated minimal effects. Thus, $78 \%$ of respondents stated the lack of gender-related courses, while $22 \%$ of them answered otherwise, indicating a deficiency of studies on gender equality, female entrepreneurship, and empowerment training. In turn, investigation results in female students' prioritization related to gender-oriented courses demonstrated that $56 \%$ of respondents were interested in developing this study area, whereas $44 \%$ indicated the opposite. Examination results in female students' prioritization for gender-oriented study subjects showed that $35 \%$ of respondents emphasized social justice as an interesting course to study, whereas $32 \%$ identified gender equality, $15 \%$ selected empowering training, 15\% - female entrepreneurship, and 3\% - introduction to gender studies (Table 5).

Table 5. Female students' preferences for gender-oriented courses

\begin{tabular}{lc}
\hline Study subject & Result (\%) \\
\hline Social justice & 35 \\
Gender equality & 32 \\
Women empowering training & 15 \\
Female entrepreneurship & 15 \\
Introduction to gender studies & 3 \\
\hline
\end{tabular}

Source: developed by the authors.

At the institutional level, the dimension comprised of stereotypes, prejudices, and social expectations. The analysis indicated that $47 \%$ of respondents accompanied stereotypes, including questioning the competence (knowledge, abilities and skills) to perform effectively and accomplish study results. Besides, $21 \%$ of respondents considered their ability to make decisions were issued, $19 \%$ perceived that their competence to lead students' group was questioned, and 13\% indicated the stereotype such as questioning their ability to solve problems related to studies (Table 6).

Table 6. Female students' attitudes of stereotypes

\begin{tabular}{lc}
\hline Type of stereotype & Result (\%) \\
\hline Competence (knowledge, abilities and skills) to perform effectively and achieve high grades & 47 \\
Competence (knowledge, abilities and skills) to make decisions & 21 \\
Competence (knowledge, abilities and skills) to lead a group of students & 19 \\
Competence (knowledge, abilities and skills) to solve problems related to studies & 13 \\
\hline
\end{tabular}

Source: developed by the authors.

Research results about situations in the classroom demonstrated that $65 \%$ of female students answered «no» on the question if they have ever felt discriminated against because of their gender. In turn, $35 \%$ of female students felt discriminated in the classroom. In comparison, $15 \%$ of female respondents did not perceive discrimination seriously, $9 \%$ responded that they were subject to disrespectful comments, $8 \%$ reported that male students had more opportunities, and $3 \%$ of female students felt discriminated due to unfair grading (Table 7).

Table 7. Female students' discrimination approach

\begin{tabular}{lc}
\hline Discrimination approach & Result (\%) \\
\hline Female students who did not perceive discrimination seriously & 15 \\
Female students were subject to disrespectful and degrading comments & 9 \\
Female students think that male students had more opportunities & 8 \\
Female students have felt discriminated due to unfair grading & 3 \\
Total & 35 \\
\hline
\end{tabular}

Source: developed by the authors. 
S., Dalati, J., Raudeliuniene, V., Davidaviciene. Innovations in the management of higher education: situation analysis of Syrian female students empowerment

Female students identified that the main confrontational factors related to people who could be confronting them were female students $(23 \%)$, male students $(22 \%)$, family $(20 \%)$, academic staff at university (17\%), and other people (18\%). Analysis related to negative barriers impact presented that $65 \%$ of students indicated that they did not care, $30 \%$ responded that it diminished their self-confidence, and $5 \%$ underlined that it made them question their decisions. The analysis of female students' support preferences demonstrated that $41 \%$ of respondents preferred psychological support, $36 \%$ supposed clear actions taken by the institution, $15 \%$ required legal assistance, and $8 \%$ - emotional support (Table 8 ).

Table 8. Female students' support preferences

\begin{tabular}{lccc}
\hline Type of support & Result (\%) & Type of support & Result (\%) \\
\hline Psychological support & 41 & Legal support & 15 \\
Institutional support & 36 & Emotional support & 8 \\
\hline
\end{tabular}

Source: developed by the authors.

The competence needs' analysis for female student training areas identified a set of soft, leadership, digital, technological, and problem-solving knowledge, abilities and skills. Therefore, $77 \%$ of female students reported that they were not provided with the competence necessary to seek a career goal in academia, whereas $23 \%$ answered positively. Descriptive analysis of required competence (knowledge, abilities, and skills) for female students illustrated the need for the following competence. $28 \%$ of the respondents diagnosed technological skills, $24.5 \%$ preferred soft skills, $24.5 \%$ required leadership skills, $16 \%$ underlined problem-solving skills, and $7 \%$ identified digital skills (Table 9 ).

Table 9. Female students' competence needs

\begin{tabular}{lc}
\hline Type of skills & Result (\%) \\
\hline Technological skills & 28 \\
Soft skills & 24.5 \\
Leadership skills & 24.5 \\
Problem-solving skills & 16 \\
Digital skills & 7 \\
\hline
\end{tabular}

Source: developed by the authors.

Female students' required competence results underlined those female students need for competencies in technological, soft, and leadership areas. A question based on a ranking scale investigated the prioritization of the courses by the strength of significance. The survey results illustrated that $43 \%$ of respondents positioned self-empowerment in the first place, highlighting this training's need and importance, 25\% assigned developing management and leadership skills to the second rank, and $14 \%$ - networking skills to the third rank of importance and magnitude (Table 10).

Table 10. Ranked training areas

\begin{tabular}{lc}
\hline Training courses & First place \\
\hline Self-empowerment & $43 \%$ \\
Developing management and leadership skills & $25 \%$ \\
Developing networking skills & $14 \%$ \\
Improving digital skills & $9 \%$ \\
Introduction to gender studies & $8 \%$ \\
Integration of gender dimensions into a research & $1 \%$ \\
\hline
\end{tabular}

Source: developed by the authors. 
S., Dalati, J., Raudeliuniene, V., Davidaviciene. Innovations in the management of higher education: situation analysis of Syrian female students empowerment

The analysis of female students at the Syrian university disclosed that female students' motivation to pursue a career in academia is evident. The study also revealed that gender dimensions were not incorporated into the faculty study program. There was no awareness of the topic among the target group of investigation. The results also indicated that female students reported interest in studying genderrelated study subjects such as women empowerment, gender equality, and social justice. The findings suggested the relevance for female role-modelling, where academic expertise was the critical factor associated with a female role model. The study disclosed the necessity for a set of disciplines to be provided to female students. In the pursuit of enhancing female students' status at the university in Syria and empowering this target group, universities in Syria should put forwards initiatives and measures to achieve progress in this scope. It is possible to realize by developing gender-oriented courses and creating an appropriate pedagogical curriculum that supports all gender issues. Besides, to promote gender awareness across all students (males and females) through role models. Another idea of how they could benefit from this situation is to incorporate a department for Psychological support offered to all Arab International University stakeholders. Despite the policies currently existing and applied at Syrian universities, they need to take further steps to meet female students' needs. Consequently, other activities should be performed to enhance the training and development departments for all stakeholders. The recommendation is to establish training curricula in addition to the academic curricula.

Conclusions. This study presented a situation analysis investigating factors which impact female students' experience and career aspirations. Female students' role models are crucial in investigating and disclosing female students' positive perceptions and attitudes towards women role models. It stands to mention that the integration of gender equality at the university strategy is an essential investigation that requires development. Herewith, the lack of awareness of gender equality and equity is a significant development area and study at Syrian universities. Besides, managing social and organizational resistance is critical and requires raising awareness for gender equality at the institutional level. The findings for female students disclose adequate levels of motivation to pursue a career in academia and interest in studying gender-oriented courses. Gender issues are not currently integrated into the faculty course offerings and curriculum. At the same time, policies related to institutional support are areas of investigation. The findings disclose that stereotypes and social expectations exist as challenges that require examination. Technological skills, soft skills, and leadership skills were identified as a set of training that is needed by female students. Self-empowerment was recognized as critical training for female students. Developing management, leadership, and networking skills were also identified as a training need for female students. As for research limitations, the main drawback is associated with the sampling strategy, which follows a non-probability sampling technique. A future research area should be focused on better sampling strategies investigation for secure representative samples as representative sampling techniques enable the researcher to perform statistical techniques and levels of analysis.

Author Contributions: conceptualization, S. D., J. R., and V. D.; methodology, S. D., J. R., and V. D; software, S. D.; validation, S.D.; formal analysis, J.R.; investigation, S. D.; resources, V. D.; data curation, S. D.; writing - original draft preparation, J. R.; writing-review and editing, V. D.; visualization, J. R.; supervision, J. R.

Funding: This research was partly supported by Erasmus+ FREE project «Female Academic Role Model Empowerment, Equality and Sustainability at Universities in Mediterranean Region: towards 2030 Agenda», No 598524-EPP-1-2018-1-ES-EPPKA2-CBHE-JP. 
S., Dalati, J., Raudeliuniene, V., Davidaviciene. Innovations in the management of higher education: situation analysis of Syrian female students empowerment

\section{References}

Afiouni, F., Karam, C. M., \& Makarem, Y. (2020). Contextual embeddedness of careers: female "nonsurvivors" and their gendered relational context. Human Resource Management Journal, 30(3), 343-364. [Google Scholar] [CrossRef]

Al Azmeh, Z., Dillabough, J., Fimyar, O., McLaughlin, C., Abdullateef, S., Aloklah, W. A., .. \& Al Mohamad Al Ibrahim, A. (2020). Cultural trauma and the politics of access to higher education in Syria. Discourse: Studies in the Cultural Politics of Education, 1-16. [Google Scholar] [CrossRef]

Alamir, I., Ayoubi, R. M., Massoud, H., \& Al Hallak, L. (2019). Transformational leadership, organizational justice and organizational outcomes. Leadership \& Organization Development Journal, 40(7), 749-763. [Google Scholar] [CrossRef]

Al-Salem, A., \& Speece, M. (2017). Women in leadership in Kuwait: a research agenda. Gender in Management, 32(2), 141162. [Google Scholar] [CrossRef]

Bordoloi, R. (2018). Transforming and empowering higher education through Open and Distance Learning in India. Asian Association of Open Universities Journal, 13(1), 24-36. [Google Scholar] [CrossRef]

Braunstein, E., \& Seguino, S. (2018). The impact of economic policy and structural change on gender employment inequality in Latin America, 1990-2010. Review of Keynesian Economics, 6(3), 307-332. [Google Scholar] [CrossRef]

Cooper, D. R., \& Schindler, P. S. (2013). Business research methods. McGraw Hill Education. [Google Scholar]

Dalati, S. (2017). Relationship Between Sustainable Leadership and Organizational Trust: Empirical Evidence from Private Higher Education Institutions in Syria. In Modernizing Academic Teaching and Research in Business and Economics (pp. 143-156). Springer, Cham. [Google Scholar] [CrossRef]

Dalati, S., \& Alchach, H. (2018). The effect of leader trust and knowledge sharing on staff satisfaction at work: investigation of universities in Syria. Business, Management and Education, 16, 190-205. [Google Scholar] [CrossRef]

Dalati, S., Raudeliuniene, J., \& Davidaviciene, V. (2017). Sustainable leadership, organizational trust on job satisfaction: empirical evidence from higher education institutions in Syria. Business, Management and Education, 15(1), 14-27. [Google Scholar] [CrossRef]

Danylova, T. V., \& Kats, L. A. (2019). «All animals are equal, but some animals are more equal than others»: The negtive impact of gender inequality on the global economy and public health. Anthropological Measurements of Philosophical Research, (15), 101110. [Google Scholar] [CrossRef]

Dariel, A., Kephart, C., Nikiforakis, N., \& Zenker, C. (2017). Emirati women do not shy away from competition: Evidence from a patriarchal society in transition. Journal of the Economic Science Association, 3(2), 121-136. [Google Scholar] [CrossRef]

Dravet, F., \& Castro, G. D. (2019). Learning, digital media and affection: proposals for a new paradigm in higher education. Interface-Comunicação, Saúde, Educação, 23. [Google Scholar] [CrossRef]

European Union. (2012). Charter of fundamental rights of the European Union (2012/C 326/02). Retrieved from [Link]

Ferrell, O. C., \& Hartline, M. D. (2008). Marketing strategy 4th ed. America: Thomson South-western.

Fonts, M. (2018). Community college minority female administrators as mentors of minority female students. International Journal of Mentoring and Coaching in Education. [Google Scholar] [CrossRef]

Gómez, J. M., \& Mouselli, S. (Eds.). (2018). Modernizing the Academic Teaching and Research Environment: Methodologies and Cases in Business Research. Springer. [Google Scholar

Gracia, L. (2009). Employability and higher education: Contextualizing female students' workplace experiences to enhance understanding of employability development. Journal of Education and Work, 22(4), 301-318. [Google Scholar] [CrossRef]

Hausmann, R., Tyson, L. D., \& Zahidi, S. (2010). Global Gender Gap Report. Retrieved from [Link]

Howard-Grenville, J., Davis, J., Dyllick, T., Joshi, A., Miller, C., Thau, S., \& Tsui, A. S. (2017). Sustainable development for a better world: Contributions of leadership, management and organizations: Submission deadline: July 1 to July 30, 2018. Academy of Management Discoveries, 3(1), 107-110. [Google Scholar] [CrossRef]

Hussain, S., \& Malik, M. I. (2018). Towards nurturing the entrepreneurial intentions of neglected female business students of Pakistan through proactive personality, self-efficacy and university support factors. Asia Pacific Journal of Innovation and Entrepreneurship. [Google Scholar] [CrossRef]

Makarem, Y., Metcalfe, B. D., \& Afiouni, F. (2019). A feminist poststructuralist critique of talent management: Toward a more gender sensitive body of knowledge. BRQ Business Research Quarterly, 22(3), 181-193. [Google Scholar] [CrossRef]

Malik, S., \& Courtney, K. (2011). Higher education and women's empowerment in Pakistan. Gender and Education, 23(1), 2945. [Google Scholar] [CrossRef]

Moodly, A., \& Toni, N. (2019, April). Intrinsic and Extrinsic Factors in Empowerment of Women Towards Leadership: A Study in Higher Education (South Africa). In ICGR 2019 2nd International Conference on Gender Research (p. 407). Academic Conferences and publishing limited. [Google Scholar]

Muborakshoeva, M. (2019). Challenges in higher education and the role of Muslim cultures and civilizations in developing a new paradigm in education. Revista Española de Educación Comparada, (33), 62-77. [Google Scholar] [CrossRef]

Popp, A. L., Lutz, S. R., Khatami, S., Van Emmerik, T. H., \& Knoben, W. J. (2019). A global survey on the perceptions and impacts of gender inequality in the Earth and space sciences. Earth and Space Science, 6(8), 1460-1468. [Google Scholar] [CrossRef] 
S., Dalati, J., Raudeliuniene, V., Davidaviciene. Innovations in the management of higher education: situation analysis of Syrian female students empowerment

Raudeliuniene, J., Davidaviciene, V., Meidute-Kavaliauskiene, I., \& Radeckyte, V. (2020). Women's leadership success factors in the Baltic states. International Journal of Learning and Change, 1-19. [CrossRef]

Raudeliuniene, J., Davidaviciene, V., Tvaronaviciene, M., \& Radeckyte, V. (2018b). A study of success factors of women' 's leadership in e-commerce. Terra Economicus, 16(3). [Google Scholar] [CrossRef]

Raudeliuniene, J., Radeckyte, V., \& Tvaronaviciene, M. (2018a). Regional development via entrepreneurship: Women leadership in lithuanian e-commerce. In Innovation Management and Education Excellence through Vision 2020 (pp. 1151-1162). [Google Scholar]

Segovia-Perez, M., Laguna-Sánchez, P., \& de la Fuente-Cabrero, C. (2019). Education for Sustainable Leadership: Fostering Women's Empowerment at the University Level. Sustainability, 11(20), 5555. [Google Scholar] [CrossRef]

Sidani, Y. (2005). Women, work, and Islam in Arab societies. Women in Management Review, 20(7), 498-512. [Google Scholar] [CrossRef]

Sidani, Y. M. (2016). Working women in Arab countries: a case for cautious optimism. In Handbook on Well-Being of Working Women (pp. 689-701). Springer, Dordrecht. [Google Scholar] [CrossRef]

Sindi, H. (2015). Building the Entrepreneurial Ecosystem in Saudi Arabia and the Middle East. In Social Entrepreneurship in the Middle East (pp. 63-88). Palgrave Macmillan UK. [CrossRef]

Sultana, S., Guimbretière, F., Sengers, P., \& Dell, N. (2018). Design within a patriarchal society: Opportunities and challenges in designing for rural women in bangladesh. In Proceedings of the $2018 \mathrm{CHI}$ Conference on Human Factors in Computing Systems (pp. 1-13). [Google Scholar] [CrossRef]

Thakur, M., Bansal, A., \& Maini, R. (2018). Job sharing as a tool for flexible work systems. Gender in Management: An International Journal., 33(5), 350-366. [Google Scholar] [CrossRef]

UNESCO. (2019). Women in Science, FS/2019/SCl/55. Retrieved from [Link]

World Economic Forum. (2018). The Global Gender Gap Report 2018 Insight Report. Retrieved from [Link]

Xheneti, M., Karki, S. T., \& Madden, A. (2019). Negotiating business and family demands within a patriarchal society-the case of women entrepreneurs in the Nepalese context. Entrepreneurship \& Regional Development, 31(3-4), 259-278. [Google Scholar [CrossRef]

Серене Далаті, Ph.D., Арабський міжнародний університет, Cирія

Юргіта Рауделюнієне, Ph.D., Вільнюський технічний університет імені Гедимінаса, Литва

Віда Давідавічене, Ph.D., Вільнюський технічний університет імені Гедимінаса, Литва

Інновації в управлінні вищою освітою: ситуаційний аналіз впливу розширення прав та можливостей сирійських студенток

У статті проаналізовано роль жінки у вищій освіті на прикладі Сирії, зокрема, після 2011 року. Авторами наголошено що процес офріційного визнання ролі жінки в економіці та в секторі вищої освіти в Сирії суповоджується низкою бар'єрів та обмежень. Метою дослідження є ситуаиійний аналіз наслідків та перспектив розширення прав $і$ можливостей сирійських студенток у секторі вищої освіти. У статті авторами висвітлилено основні бар'єри та обмеження у секторі вищої освіти на прикладі Арабського міжнародного університету (Сирія) Методологічний інструментарій дослідження кількісний підхід до розроблення структурованої анкети для проведенення опитування. Авторами було сфрормовано вибірку даних за результатми опитування 98 студенток, що навчаються на семи фракультетах Арабського міжнародного університету (Сирія). На основі отриманих емпіричних даних, авторами наголошено на необхідності підвищення рівня обізнаності студентів щодо гендерної рівності та рівноправності в університетах Сирії. Встановлено, що питання гендерної рівності не були включені до навчальної програми студентів Арабського міжнародного університету (Сирія). Доведено, що студентки мають достатній рівень мотивації для продовження наукової кар'єри та зацікавленні у вивченні навчальних дисциплін, присвячених гендерним питанням. У ході дослідження авторами зроблено висновок про існування низки стереотипів та соціальних очікувань від ролі жінки у вищій освіті Сирії. Таким чином, рівень самооиінки має бути головним аспектом в підготовиі студенток у закладах вищої освіти. Авторами наголошено, що студентки повинні мати можливість брати участь у заходах, присвячених розвитку технологічних вмінь, навичок міжособистісного спілкування та лідерства. Результати дослідження вказують на необхідність проведення подальших досліджень щодо інтегращії питань гендерної рівності в стратегію університету.

Ключові слова: жіночий, гендер, студент, вища освіта, розширення можливостей жінок, університет.

Manuscript received: 10.06 .2020

(C) The author(s) 2020. This article is published with open access at Sumy State University 